\title{
KESENJANGAN DALAM \\ PEMBANGUNAN KEWILAYAHAN
}

\author{
Saratri Wilonoyudho \\ Jurusan Teknik Sipil Universitas Negeri Semarang \\ Gedung E Lantai 2 Kampus Sekaran Gunungpati Semarang \\ E-mail: saratri@telkom.net
}

\begin{abstract}
The purpose this paper is to provide a broad overview of the recent patterns and trends of urban growth, and to discuss the relationship between urbanization and regional imbalaces in Indonesia, and also to asses the policy implication. Over the last 20 years many urban areas have experienced dramatic growth, as a result of rapid population growth and as the world's economny has been transformed by a combination of rapid technological and political change. The population of the cities roughly doubles when we add the zones to the metropolitan core. In the cases of Semarang, there is much more than a doubling. The inner zones are where the action is migrant come there from both the core and elsewhere in the country. Net migration in many cases contributes as much as two thirds of the population growth in these zones, whereas in the city cores, net migration contributes little to growth. A comprehensive model suggest that regional imbalances in Indonesia is influenced by economic-structural and social demographic factors
\end{abstract}

Keywords : population growth, urbanization, regional imbalances

\section{PENDAHULUAN}

Isu keadilan dalam pembangunan kewilayahan, selalu menjadi perbincangan hangat, terutama terkait dengan masalah "kesenjangan wilayah" (regional imbalances). Sampai saat ini isu kesenjangan wilayah terpusat kepada kesenjangan antara desa dan kota, antara Kawasan Timur Indonesia dan Kawasan Barat Indonesia, serta antara Jawa dan luar Jawa. Banyak pakar yang percaya bahwa kesenjangan wilayah merupakan harga wajar yang harus dibayar dalam proses pembangunan. Sederhana saja alasannya, yakni ada keterkaitan antara wilayah satu dengan wilayah yang lain sebagai sebuah sistem. Dengan kata lain ada proses interaksi dan interdependensi antar subsistem.

Indikator yang digunakan untuk memperlihatkan bahwa sebuah wilayah dianggap lebih maju dibandingkan dengan wilayah yang lainnya cukup banyak. Hill (1993) misalnya menyebut indikator yang bersifat statis seperti Indeks Pembangunan Manusia (buman development index), Indeks Kualitas Kehidupan secara Fisik (physical quality of life index), maupun laju PDRB (product domestic regional bruto). Data seperti ini meskipun tidak secara absolut dapat dipercaya begitu saja, namun dapat digunakan sebagai gambaran awal betapa sebuah wilayah lebih maju dibanding 
wilayah yang lain. Sebagai contoh Jakarta yang memiliki PDRB per kapita sebesar 1,76 juta rupiah pada tahun 1991, jauh lebih tinggi dibanding rata-rata PDRB per kapita secara nasional yang hanya 0,55 juta rupiah pada tahun yang sama.

Gambaran sederhana ini hanya ingin menunjukkan bahwa Jakarta berkembang terlalu pesat dibandingkan dengan wilayah propinsi di Indonesia yang lain, yang antara lain ditandai dengan jumlah uang yang beredar di Jakarta mencapai 70\% dari peredaran uang nasional. Fakta ini juga menunjukkan bahwa pembangunan sebuah wilayah dipengaruhi oleh sebuah faktor penting, yakni investasi pembangunan daerah, sedangkan kesenjangan wilayah terjadi jika alokasi investasi antardaerah juga timpang (Aziz,1985).

Menurut Aziz lebih lanjut, jika sudah sampai pada titik alokasi investasi antardaerah, maka berbicara tentang sistem ekonomi politik negara juga sangat penting artinya. Selama ini terlihat bahwa pendekatan sektoral dalam perencanaan pembangunan senantiasa dikaitkan dengan pertanyaan tentang : sektor apa yang akan dikembangkan (birarki 2) untuk mencapai tujuan pembangunan nasional (birarki 3). Sub pertanyaan dapat berbentuk : berapa banyak harus diproduksi, dengan cara teknologi apa, kapan dimulai, dan sebagainya. Setelah tahapan ini selesai baru muncul pertanyaan di mana aktivitas tiap sektor akan dijalankan (birarki 3), baru ditutup dengan pertanyaan standar : kebijakan apa, strategi apa, dan langkahlangkah apa yang akan diambil (birarki 4). Pendekatan yang lazim digunakan dalam analisis wilayah adalah pendekatan regional (Kiswanto, 2005).

Berbeda dengan pendekatan sektoral, pendekatan regional lebih menitikberatkan kepada pertanyaan : daerah mana yang perlu mendapat prioritas untuk dikembangkan, baru kemudian sektor apa yang sesuai untuk dikembangkan di masing-masing daerah. Dengan kata lain, birarki 2 dan birarki 3 dapat bertukar tempat.

Teori pertumbuhan wilayah dimulai dari model dinamika wilayah yang sederhana sampai dengan model yang komprehensif, mulai dari teori resource endowment, teori export base, teori pertumbuhan wilayah neoklasik, model ketidakseimbangan pertumbuhan wilayah dan sebuah teori baru mengenai pertumbuhan wilayah. Teori resource endowment mengatakan bahwa pengembangan ekonomi bergantung sumberdaya alam yang dimiliki dan permintaan terhadap komoditas yang dihasilkan dari sumberdaya itu (Perloff and Wingo, 1961).

Teori export base atau teori economic base dikembangkan oleh North (1955), yang intinya mengatakan bahwa pertumbuhan wilayah jangka panjang bergantung pada kegiatan industri ekspornya. Dengan kata lain, jika permintaan eksternal barang dan jasa yang dihasilkan dan diekspor dari wilayah itu tinggi, maka wilayah itu disebut memiliki kekuatan yang baik. Selanjutnya teori pertumbuhan wilayah neoklasik dikembangkan oleh Richardson (1973) meneruskan teori sebelumnya dari Borts (1960) dan Siebert (1969). Menurut teori ini pertumbuhan ekonomi sebuah wilayah berhubungan dengan tiga faktor penting, yakni tenaga kerja, ketersediaan modal, dan kemajuan teknologi.

Teori-teori yang berkembang kemudian berkaitan dengan upaya-upaya untuk memperkenalkan perkembangan teknis investasi secara eksplisit dan mandiri, sehingga perubahan itu tanggap terhadap dorongan ekonomis. 
Berdasarkan latar belakang masalah tersebut muncul pertanyaan penelitian: 1). Seberapajauh terjadi kesenjangan pembangunan wilayah di Indonesia? 2). Implikasi apakah yang terjadi dalam konteks sosialekonomi-politik akibat adanya kesenjangan pembangunan kewilayahan?

Tujuan penelitian ini untuk mempelajarai dan menjelaskan sejauhmana telah terjadi kesenjangan dalam pembangunan kewilayahan di Indonesia serta impilikasi apakah yang terjadi akibat dari kesenjangan ini, khususnya dalam konteks sosialekonomi-politik. Diharapkan hasil penelitian ini dapat memperjelas masalahmasalah pembangunan kewilayahan pada umumnya dan dapat digunakan sebagai dasar untuk pengambilan keputusan.

\section{METODE PENELITIAN}

Penelitian ini mengungkap makna dari suatu fenomena kesenjangan pembangunan kewilayahan dengan berbagai sebab dan akibatnya, menggunakan data berupa angka-angka, data atau informasi yang berkaitan hasil survai BPS atau instansi terkait lainnya. Pemahaman terhadap data dan informasi ini dilakukan secara wajar tanpa dimanipulasi dan diatur dengan eksperimen atau tes. Dengan kata lain, penelitian ini merupakan perpaduan antara penelitian kuantitatif dan kualitatif, agar dapat saling melengkapi (Brannen, 1997). Menurut Nasution (1988) penelitian kualitatif-naturalistik memiliki karakter : 1). Bertujuan memperoleh gambaran yang lebih mendalam; 2). Bertujuan untuk memahami makna dari suatu fenomena; 3). Memandang fenomena secara utuh dan holistik; 4). Desain penelitian bersifat emergensi, artinya terbuka untuk disempurnakan.
Penelitian ini menggunakan pendekatan kompleks wilayah. Pada tahap operasionalnya pendekatan dilakukan secara terpadu, unit wilayah Kota Semarang dan daerah di belakangnya diidentifikasi perbedaan dan persamaannya sesuai tujuan penelitian, atau teknik diferensiasi areal melalui teknik klasifikasi. Wilayah bukan tujuan akhir studi ini (objective region) melainkan sebagai alat (subjective region) untuk mempelajari kelompok gejala yang ada di wilayah tersebut.

\section{A. Teknik Pengumpulan Data}

Sumber data utama penelitian ini adalah angka-angka hasil Survai BPS dan instansi terkait serta hasil penelitian terdahulu. Data sekunder dari hasil survai BPS dan hasil penelitian lainnya. Teknik pengumpulan data dilakukan dengan metode dokumentasi. Variabel dari penelitian ini, antara lain:

1. Variabel Tergantung (Dependent Variable) : Kesenjangan Wilayah

2. Variabel Bebas (Independent Variable):

a. Perubahan penduduk

Indikator: Jumlah penduduk, kepadatan, struktur (umur, jenis kelamin, pekerjaan, dan pendidikan), rasio penduduk kota-desa, rasio tenaga kerja yang bekerja di sektor industri.

b. Pertumbuhan ekonomi

Indikator: Pertumbuhan PDRB, jumlah dan pertumbuhan industri besar, sedang dan kecil, sumbangan sektor industri terhadap total PDRB.

\section{B. Metode Analisis}

Berbagai dokumen kebijakan tersebut dianalisis setelah dikaitkan 
dan digabungkan dengan fakta-fakta dan data lain. Untuk mengecek kebenaran data juga dilakukan triangulasi data. Hasil analisis yang diharapkan adalah untuk menemukan makna-makna di balik pergeseran kebijakan pembangunan ekonomi dan kebijaksanaan kependudukan dalam kaitannya dengan dampak kesenjangan pembangunan wilayah. Mengacu kepada pendapat Miles dan Haberman (1992), model analisis isi (content analysis model) digunakan untuk menganalisis substansi berbagai dokumen peraturan dan berbagai dokumen kebijakan pembangunan lainnya. Berbagai data dan analisis tersebut dipadukan dengan model analisis interaktif (interactive analysis model).

\section{HASIL DAN PEMBAHASAN}

\section{A. Kesenjangan Desa-Kota}

Pembangunan kewilayahan terkait erat dengan sistem ekonomi-politik sebuah negara. Hal ini juga disepakati oleh Hill (1996), bahwa dengan kebijasanaan pusat akan terjadi sebuah keputusan untuk mengembangkan wilayah mana saja, dan akan "mengorbankan" wilayah yang lain. Pada masa Orde Baru untuk mengembangkan sebuah wilayah dianut konsep kutub pertumbuhan. Konsep ini menurut Douglass (1998) dilakukan dengan jalan mengalokasikan investasi yang tinggi di sektor industri di pusat kota yang besar. Harapannya, pertumbuhan ekonominya dapat menyebar dan membangkitkan pembangunan wilayah di sekitarnya (spread effect dan trickle down effect). Asumsinya, barang-barang yang dihasilkan diekspor ke luar dan pusat-pusat metropolitan untuk menjadi "mesin pembangunan" (engine of development).

Konsep kutub pertumbuhan mengasumsikan bahwa industrialisasi dipandang sebagai resep yang mujarab untuk mengurangi kemiskinan, keterbelakangan, dan pengangguran di negara-negara sedang berkembang. Dengan kata lain, sebuah transformasi ekonomi akan diciptakan. Dengan industrialisasi, diharapkan akan muncul peluang kerja dan mampu menampung luapan kerja dari sektor pertanian. Lebih lanjut, proses tersebut diharapkan akan menghasilkan integrasi sistem dari pusatpusat pertumbuhan yang berbeda ukuran, fungsi dan karakteristiknya agar dapat memainkan peranannya dalam menyebarkan pembangunan wilayah.

Di negara-negara berkembang diasumsikan ada produk pertanian yang dapat dipacu produktivitasnya sehingga akan mencapai tingkat tertinggi dalam produksi pangan, memperluas kesempatan kerja dan pendapatan pada sebagian besar masyarakat, terutama dalam level subsisten. Dari titik inilah diharapkan tumbuh usaha kecil menengah usaha farm, ada pergerakan modal, ada kredit, teknologi dengan riset. Dengan mendorong kerangka institusional di perdesaan, maka dapat mendorong pertumbuhan regional.

Selanjutnya melalui integrasi ke sistem pasar dapat keuntungankeuntungan sebagai berikut : 1). Menumbuhkan skala ekonomi yang efeknya dapat menyebar di perdesaan; 2). Membantu mengorganisir ekonomi 
perdesaan di daerah belakanganya (binterland) dengan : penawaran atau supply, pasar dan administratif; 3). Harus ada inovasi agar enterpreuner atau wirasusahawan dapat terbentuk; 4). Ada investasi yang kembali yang dapat digunakan untuk pembangunan ke depan.

Dalam kenyataannya, strategi kutub pertumbuhan ini tidak cocok di negara-negara berkembang seperti Indonesia, karena ada dualisme antara sektor pertanian dan industri. Pada satu sisi sektor pertanian banyak mengalami hambatan karena lahan pertanian -terutama- di Jawa sangat sempit karena ada fragmentasi atau pewarisan. Pada sisi lain, sektor industri sangat padat modal dan berorientasi kepada substitusi impor. Kendali ada di Negara-negara maju, dan Indonesia hanya sebagai "tukang jahit". Akibatnya hanya tenaga kerja terampil saja yang dapat memasuki sektor industri. Adanya urban bias semacam ini mengakibatkan tumbuhnya sektor informal, karena luapan tenaga kerja dari sektor pertanian tidak banyak yang dapat ditampung di sektor industri. Teori-teori dari Boeke (1961) tentang dualisme sektor ekonomi maupun dari Geertz tentang involusi pertanian banyak menjelaskan tentang kemiskinan dan peluang kerja di perdesaan.

Banyak studi yang telah dilakukan untuk memahami akibat-akibat negatif dari program Revolusi Hijau tersebut yang umumnya disimpulkan banyak memperlebar kesenjangan antara pendapatan kaum petani miskin dibandingkan dengan pendapatan para petani kaya. Akibat yang timbul umumnya berkaitan dengan komer- sialisasi dalam pengambilalihan keputusan, terutama dalam bidang produksi. Hal ini dapat dipahami, mengingat beberapa sarana produksi umumnya dibeli dari luar desa. Komersialisasi ini umumnya bukan berasal dari hubungan harga, melainkan dari kenaikan hasil-hasilnya yang besar sekali. Kenaikan ini menyebabkan surplus yang besar bagi tuan tanah. Para petani kaya yang menikmati surplus ini, telah mengumpulkan sebagian besar tanah di tangan mereka dan kemampuan untuk menanam lebih intensif dalam memperbesar surplus mereka.

Pada sisi lain banyak pula studi yang menunjukkan bahwa lembagalembaga tradisional pedesaan tidak efektif dalam menjamin kebutuhan subsistensi petani kecil. Dalam sistem masyarakat tradisional, eksternalitas produksi dan biaya informasi nampak sedemikian tinggi, sehingga pemanfaatan pranata-pranata nonpasar oleh kelompok elite di pedesaan, dinilai memberikan keuntungan besar. Para petani kaya umumnya cenderung melakukan hubungan ekploitatif, dengan memanfaatkan statusnya dalam kekuasaan politik atau status sosialnya.

Bukti-bukti yang lain sebagaimana dikatakan William Collier dalam bukunya yang berjudul Rural Development in the Decline in Traditional Village Welfare Institution in Java. Collier mengemukakan betapa polarisasi sosial ekonomi dan deferensiasi kelas telah banyak terjadi di daerah pedesaan di Jawa Tengah, Hal ini menurutnya karena adanya perubahan-perubahan teknologi. Dengan memanfaatkan teknologi, petani-petani bertanah luas 
tersebut berusaha memperbesar keuntungan tanpa banyak mempekerjakan tenaga kerja manusia. Contoh ini menunjukkan betapa polarisasi sosial ekonomi dapat terjadi karena struktur pemilikan tanah yang timpang. Melalui komersialisasi pertanian di satu sisi, serta semakin sempitnya lahan pertanian pada sisi yang lain, telah banyak membawa dampak yang cukup serius di daerah pedesaan. Sementara itu, ledakan penduduk yang hebat tambah memperburuk keadaan, seperti semakin sempitnya peluang kerja di pedesaan.

Pembangunan sektor pertanian yang terintegrasi dengan sektor industri nampaknya berhasil dilakukan oleh pemerintah Cina. Slogan Cina adalah "Leave agriculture, but not the country side" serta "enter the factory, but not the city". Artinya pemerintah Cina mempersilakan warga desa untuk meninggalkan pertanian, namun jangan tinggalkan desa, dan memperbolehkan memasuki basis manufaktur, namun jangan masuk kota. Himbauan ini mengandung nilai filosofis yang tinggi. Kalau hanya dipahami secara harfiah maka orang akan terjebak.

Cina tentu berbeda dengan negaranegara Asia lainnya termasuk Indonesia, dimana revolusi hijau (green revolution) telah gagal mencapai hasil yang diharapkan karena berbagai sebab seperti pewarisan tanah yang terus menerus (fargmentasi) dan tidak adanya jalinan produksi dengan sektor moderen. Di Indonesia yang terjadi malahan keterkaitan konsumsi (consumption linkage). Artinya kota-kota besar di Indonesia malahan menjadi "parasit" dan menyedot sumberdaya desa secara gila-gilaan. Tetesan ke bawah (trickle down effect) dan sebaran kemakmuran (spread effect) tidak terjadi!

Akibatnya dapat diduga, arus migrasi dari desa ke kota di negeri ini luar biasa. Tahun 2008 Jawa Tengah mengirimkan 13.000 tenaga kerja ke Jakarta dalam arus balik lebaran (Lihat SM edisi Oktober 2008) lalu. Ini artinya, desa-desa di tanah air mengalami kelangkaan kesempatan kerja. Justru produk-produk moderen dari kota dan dari pusat kapitalisme dunia deras mengalir ke desa. Hadirnya puluhan stasiun TV swasta, makin menyuburkan pola konsumsi masyarakat desa.

Sebaliknya di Cina, tanah sawah dilarang keras untuk dipecah-pecah atau dijual. Namun di luar status politik dan pemerintahan negara Tirai Bambu itu, visi dan misi yang jelas untuk membangun desa telah dijalankan secara konsisten dan konsekuen. Hasilnya adalah para "township village enterprise", dan konsep agropolitan terbentuk dengan bagusnya. Ini semua berkat efek simultan antara pembangunan desa dan kota. Karenanya, Cina adalah negara berpenduduk padat yang tidak risau terhadap persoalan migrasi sebagaimana Indonesia ketika idul fitri tiba.

Dari sketsa tersebut nampak bahwa kalau negara-negara maju mengalami proses yang simultan antara sektor pertanian dan sektor moderen, maka negara-negara berkembang seperti Indonesia tidak demikian. Di Negara-negara berkembang -kecuali Cina- industri yang dikembangkan adalah industri substitusi impor, dan pusat kapitalisme tetap ada di New York, Berlin, London, atau Tokyo. Wajar jika modernisasi pertanian terhambat dengan serius. 
Negara-negara besar amat ketat mengontrol teknologinya, sehingga Indonesia hanya tergantung dari negara-negara maju. Menurut Kepala Badan Pengkajian dan Penerapan Teknologi (BPPT), Marzan Aziz Iskandar, saat ini sumber teknologi Indonesia di sektor industri masih impor sebesar $92 \%$. Sumber teknologi impor itu ialah : 37\% dari Jepang, 27\% dari negara-negara Eropa, 9\% dari Amerika, 9\% dari Taiwan, 4\% dari China, 3\% dari Korea Selatan, 2\% dari India, dan 1\% dari Thailand (Kompas,30/12/2009).

Demikian pula perusahaan multinasional negara-negara maju yang beroperasi di negara-negara berkembang, sangat ketat mengontrol penguasaan teknologinya, ketimbang mengontrol penguasaan modal. Akibat kontrol teknologi yang ketat dari "pemiliknya", maka perusahaanperusahaan atau industri di dalam negeri juga hanya tergantung dari Negara-negara maju. Mereka hanya menggunakan alat, dan tidak memiliki Research and Development (R \& D). Apalagi hubungan industrial akan bergantung pula kepada eskalasi pengendalian teknis atas penguasaan alam, peningkatan administrasi manusia dan hubungan diantara mereka melalui manipulasi-manipulasi organisasi sosial-politik.

Industri rakyat pedesaan perlu dibantu alat teknologi tepat guna (TTG), perlu pendampingan, pemasaran, informasi pasar, pameran, dan sebagainya. Lebih lanjut, sangat ideal jika antara industri besar dan industri kecil di pedesaan yang menggunakan alat TTG ada keterkaitan (backward lingkage and forward linkage). Coba tanya para pelaku industri kerakyatan dan petani kecil, apakah dengan meningkatnya penjualan mie instant kemasan, makanan dan minuman kemasan, jamu kemasan, atau produksi otomotif dan elektronik, para petani cabai, petani bawang, petani rempah-rempah, industri cor, dst, makin sejahtera ? Apakah mereka diajak bekerjasama sebagaimana disaksikan di negeri tirai bambu Cina?

Peningkatan konsumsi masyarakat mestinya akan meningkatkan permintaan dan berarti industri akan sibuk melayani. Selanjutnya jika industri besar yang padat modal maju, maka permintaan terhadap bahan baku atau bahan mentah dari petani juga akan meningkat. Namun yang terjadi, para industriawan memonopoli segalanya, mulai dari hulu hingga hilir. Bahkan untuk urusan kedelai atau gula, negeri ini harus impor.

\section{B. Kesenjangan Pembangunan Kawasan Barat Indonesia dan Kawasan Timur}

Sudah menjadi isu umum bahwa pembangunan wilayah antara Kawasan Barat Indonesia (KBI) dan Kawasan Timur Indonesia (KTI) telah terjadi kesenjangan. Hasil studi Nurzaman (1997) menunjukkan bahwa kesenjangan kedua kawasan tersebut tidak terjadi dalam semua hal, namun hanya dalam bidang ekonomi. Indikator yang digunakan dalam bidang ekonomi adalah : 1). Jumlah pendapatan per kapita; 2). Pertumbuhan pendapatan per kapita; 3). Tingkat partisipasi angkatan kerja; 4). Persentase nilai tambah sektor manufaktur terhadap PDRB total propinsi; 5). Persentase tenaga kerja yang bekerja di sektor manufaktur dibandingkan tenaga kerja 
total propinsi; 6). Tingkat penanaman modal asing dan dalam negeri secara kumulatif; 7). Persentase penduduk yang tinggal di perkotaan; dan 8). Panjang jalan $/ 10.000 \mathrm{~km}$ persegi luas propinsi.

Pada bidang sosial, kesenjangan ditunjukkan oleh fakta dengan indikator seperti : 1). Physical Quality of Life Index; 2). Jumlah murid sekolah dasar dibanding jumlah total penduduk; 3). Persentase tenaga keja yang berpendidikan akademi atau universitas; 4). Rasio guru sekolah dasar tiap 10.000 murid; 5). Rasio dokter setiap 10.000 penduduk; dan 6). Rasio tempat tidur sakit tiap 10.000 penduduk.

Berdasarkan indikator-indikator tersebut, memang benar ditemukan adanya kesenjangan wilayah yang cukup besar antara kawasan Barat Indonesia dan kawasan Timur Indonesia, yakni indeks rata-rata KBI dan KTI masing-masing 108,2-81,5 (1971), 110,7-75,9 (1980), dan 112,972,2 pada tahun 1990 (Nurzaman,1997). Namun jika dirinci setiap sektor ekonomi, maka sektor gas, minyak dan pertambangan memberikan kontribusi besar di beberapa propinsi di Sumatera Selatan (minyak dan batubara), Papua (tembaga, emas), Sulawesi (nikel). Sedangkan sektor Jasa keuangan, bank, industri pengolahan, bangunan, konstruksi, pengangkutan, komunikasi, dan sebagainya, hanya terkonsentrasi di propinsi-propinsi yang maju seperti DKI Jakarta serta Jawa.

Distribusi persentase PDRB Jakarta sekitar 16,06 \% pada tahun 2007 dan pada tahun yang sama NTT, NTB, Papua Barat dan Papua masing-masing hanya $0,54 \%, 0,95 \%$, $0,29 \%$, dan $1,57 \%$ (BPS,2008). Data ini menunjukkan betapa ketimpangan wilayah semakin nyata, dan untuk lebih lengkap lagi, tabel 1 akan menunjukkan bahwa kesenjangan wilayah itu benar-benar tampak nyata.

Aziz (1985) pernah mengusulkan adanya keterpaduan antara pendekatan pembangunan wilayah secara sektoral dan regional. Selama ini pembangunan regional hanya untuk konteks-konteks

Tabel 1. PDRB Kawasan Barat Indonesia dan Kawasan Timur Indonesia Atas Dasar Harga yang Berlaku. Tahun 2004-2007

\begin{tabular}{llcccc}
\hline \hline \multirow{2}{*}{ No } & \multicolumn{1}{c}{ Lokasi } & \multicolumn{2}{c}{ Tahun } \\
& & \multicolumn{2}{c}{$\mathbf{2 0 0 5}$} & $\mathbf{2 0 0 6}$ & $\mathbf{2 0 0 7}$ \\
\hline 1. & Kawasan Barat & $1.334 .416 .111,28$ & $1.403 .282 .343,24$ & $1.482 .387 .666,82$ & $1.569 .102 .789,93$ \\
& $\begin{array}{l}\text { Indonesia } \\
\text { 2. }\end{array}$ & & & & \\
& Kawasan Timur \\
Indonesia & $269.619 .976,69$ & $286.947 .071,64$ & $295.606 .819,07$ & $308.915 .982,88$ \\
& & & & \\
\hline
\end{tabular}

Sumber: BPS 2004-2007 
Tabel 2. Laju Pertumbuhan PDRB dalam Persen Kawasan Barat Indonesia dan Kawasan Timur Indonesia Atas Dasar Harga yang Berlaku. Tahun 2004-2007

\begin{tabular}{lllll}
\hline \hline \multirow{2}{*}{ No. } & Lokasi & \multicolumn{4}{c}{ Tahun } \\
\cline { 2 - 5 } & $\mathbf{2 0 0 4}$ & $\mathbf{2 0 0 5}$ & $\mathbf{2 0 0 6}$ & $\mathbf{2 0 0 7}$ \\
\hline $\begin{array}{l}\text { 1. } \\
\begin{array}{l}\text { Kawasan Barat } \\
\text { Indonesia }\end{array}\end{array}$ & 5,16 & 5,64 & 5,85 & 5,34 \\
$\begin{array}{l}\text { 2. } \\
\begin{array}{l}\text { Kawasan Timur } \\
\text { Indonesia }\end{array}\end{array}$ & 6,43 & 3,02 & 4,50 & 3,99 \\
\hline
\end{tabular}

Sumber: BPS 2004-2007

Tabel 3. Laju Pertumbuhan PDRB dalam Persen Kawasan Barat Indonesia dan Kawasan Timur Indonesia Atas Dasar Harga yang Berlaku. Tahun 2004-2007

\begin{tabular}{|c|c|c|c|c|c|}
\hline \multirow{2}{*}{ No. } & \multirow{2}{*}{ Lokasi } & \multicolumn{4}{|c|}{ Tahun } \\
\hline & & 2002 & 2003 & 2004 & 2005 \\
\hline \multirow{2}{*}{\multicolumn{2}{|c|}{ 1. Jawa }} & 17.118 & 16.607 & 16.901 & 16.995 \\
\hline & & $80,09 \%$ & $81,71 \%$ & $81,71 \%$ & $81,99 \%$ \\
\hline \multirow{2}{*}{\multicolumn{2}{|c|}{2 Luar Jawa }} & 4.028 & 3.717 & 3.784 & 3.734 \\
\hline & & $19,05 \%$ & $18,29 \%$ & $18,29 \%$ & $18,01 \%$ \\
\hline
\end{tabular}

Sumber: BPS 2004-2007

daerah tertentu seperti daerah perbatasan, daerah terbelakang, atau daerah dengan potensi strategis. Munculnya ide Kawasan Pembangunan Ekonomi Terpadu (KAPET) juga kawasan agropolitan, dsb, menunjukkan hal itu.

Sayangnya pembangunan kawasankawasan khusus tersebut tidak disertai strategi yang tepat, dan sering hanya bernuansa politis, terutama terkait dengan isu desentralisasi saat ini. Konsep Agropolitan yang pernah dilontarkan oleh Friedman dan Douglas, misalnya, mengusulkan sebuah wilayah dengan konsentrasi aktivitas pembangunan yang dihuni sekitar 50.000 sampai 150.000 orang saja. Perencanaan dan pengambilan keputusan didesentralisasikan agar masyarakat bertanggungjawab terhadap pembangunan di daerahnya. Friedman dan Douglas membayangkan adanya gaya hidup urbanism di perdesaan akibat semakin meluasnya hubungan sosial masyarakat pedesaan yang menerobos sekat-sekat geografis di luar, sehingga terbentuk sebuah sosio-ekonomi-politik yang lebih luas.

Namun yang terjadi keterpaduan antara kegiatan pertanian dan nonpertanian untuk memperluas kesempatan kerja, sulit tercapai, bahkan yang terjadi adalah perubahan gaya hidup urbanism yang disertasi keretakan 
sosial (social disorder). Hal ini terjadi karena hubungan antara alam dan manusia dalam konsep agropolitan juga sering alpa untuk dijaga. Mestinya dalam pengembangan pertanian, maka tata guna air juga harus diperhatikan, dan diselaraskan dengan konsep-konsep industrialisasi. Fakta yang ada menunjukkan perebutan sumberdaya air pernah muncul, dengan alasan desentralisasi. Di satu pihak pemerintah yang berada di kawasan bukit merasa tidak dibantu oleh kawasan di bawahnya yang ikut memanfaatkan sumberdaya air, misalnya turut mengalokasikan anggarannya untuk penghijauan dan konservasi air. Konflik semacam ini pernah terjadi antara pemerintah Kabupaten Boyolali dan Pemerintah Kota Surakarta yang notabene menggunakan sumberdaya air dari Boyolali untuk kepentingan air minum.

Idealnya memang untuk memaksimalkan terwujudkan konsep agropolitan, perlu dibentuk sebuah agropolitan district yang memiliki kewenangan dan otoritas untuk mengatur daerahnya sendiri. Asumsinya, mereka adalah pihak yang paling paham potensi, permasalahan dan cara pemecahannya untuk mencapai tingkat penghidupan yang terbaik dan cocok bagi kelompoknya. Dari titik inilah pemerintah pusat harus dapat berperan sebagai fasilitator saja serta membantu kesulitan yang tidak dapat dipecahkan oleh mereka;

Peran pemerintah dalam menunjang agropolitan adalah adanya tata sosialekonomi-politik yang dapat melindungi masyarakat dari persaingan yang tidak sehat, rusaknya tata sosial petani lokal akibat desakan dari ekonomi maju di luar, tata perdagangan, tata kepemilikan lahan, produksi, pemasaran, dan perlindungan lain yang tidak mampu dilakukan mereka. Pada sisi lain, Stohr mengusulkan "selective spatial closure" untuk menjaga kota-kota kecil dan penduduk perdesaan dari berbagai efek akibat berinteraksi antara desa dan kota; Dari titik ini peran pemerintah juga penting diantaranya : melindungi tata ruang agropolitan dengan penguatan pola tata ruang dan berbagai infrastruktur yang dibutuhkan. Kesemuanya ditujukan untuk memperkuat tata sosial-ekonomi dan sumberdaya pertanian yang ada. Demikian pula perlu sebuah strategi untuk mewujudkan tata sumberdaya pertanian agropolitan yang dapat memberikan perlindungan mengenai sebaran ruang dari tiap-tiap komoditas pertanian, serta berbagai ketentuan teknis-ekologis yang disyaratkan.

Konsep agropolitan juga harus didukung oleh perlindungan, penguatan, dan penguatan mekanisme hubungan institusional baik horizontal atau vertikal, misalnya dengan masyarakat adat, organisasi kemasyarakatan, lembaga pemerintah, LSM, yang kesemuanya berfokus untuk mem-perkuat konsep agropolitan dan berusaha melindungi petani lokal.

\section{Pengembangan Wilayah Kawasan Khusus}

Pengembangan wilayah yang dilaksanakan di Indonesia setidaknya meliputi tiga tingkatan, yakni pada tingkat mikro, meso, dan tingkat makro. Pada tingkat mikro bertujuan untuk mengenali kebutuhan yang mendesak dan memenuhi kebutuhan dasar masyarakat, membantu daerah dalam rangka mencapai kemandirian ekonomi dan meningkatkan daya saing, serta mendorong pengembangan potensi daerah agar mampu meng- 
ekspor hasil industri atau pertaniannya, untuk mendukung perekonomian nasional (Soedjito, 1997).

Pada tingkat meso dilakukan pengembangan wilayah dengan jalan mengaitkan antar-wilayah agar tercipta pusat-pusat pertumbuhan. Kawasan yang menjadi prioritas diantaranya : kawasan cepat tumbuh, kawasan perbatasan, kawasan potensial. Banyak istilah yang dilontarkan untuk menandai strategi ini, misalnya : kawasan pembangunan ekonomi terpadu (Kapet), Kawasan Sijori, atau Kawasan perkotaan seperti Jabodetabek (Jakarta,Bogor, Depok, Tangerang, Bekasi), Bandung Raya, Kedungsepur (Semarang, Demak, Ungaran, Purwodadi), Gerbangkertasusilo (Gresik, Bangkalan, Mojokerto, Surabaya, Lamongan, Sidoardjo), Joglosemar (Jogja, Solo, Semarang), dan sebagainya.

Terlepas dari apapun namanya, upaya yang hendak dilakukan adalah untuk mengaitkan antarwilayah (kota) agar tercipta pusat-pusat pertumbuhan. Masalah yang sering muncul, sebutan kawasan-kawasan tersebut hanya berhenti sebagai slogan, tanpa visi misi yang jelas. Apalagi kini desentralisasi telah menempatkan kepala daerah atau walikota memiliki kekuasaan yang 'mutlak', maka yang terjadi tetap egoisme daerah.

Mestinya, pengembangan kawasan kota seperti itu, strateginya diarahkan untuk mencapai hal-hal sebagai berikut:

1. Lebih memperjelas hirarkhi kota dengan menghindari dominasi kota inti terhadap daerah di belakangnya tersebut. Upaya ini sebagai salah satu cara untuk membuat counter magnet daerah belakangnya tersebut sehingga timbul keserasian pembangunan antarwilayah.
Harapannya, arus urbanisasi ke pusat kota dari daerah sekitarnya tersebut dapat dikurangi;

2. Kota inti yang relatif memiliki sarana dan prasarana lebih lengkap, seperti bandar udara, pelabuhan peti kemas, lembaga finansial, sektor industri dan jasa, dan sebagainya diharapkan dapat lebih menyebarkan hasil-hasil pembangunan (spread effect and trickle down effect), agar kota utama tidak berpotensi menjadi "parasit" yang mengeksploitasi daerah di belakangnya;

3. Dari dua hal tersebut, kerjasama yang erat diantara wilayah tersebut harus diwujudkan dalam visi, misi, dan tindakan nyata di lapangan karena pengembangan dan pertumbuhan kota seakan tidak mengenal batas wilayah administratif. Dengan kata lain ada semacam joint planning untuk menuju satu integrated regional development program yang jelas dan reasonable dalam segala aspek. Jika hal ini tidak disadari dan dilakukan langkah nyata, maka Semarang dan sekitarnya akan menyatu menjadi satu megaurban yang sarat dengan berbagai permasalahan. Jika gagal maka biaya yang harus dikeluarkan untuk mengatasi masalah yang kompleks tersebut jauh di atas hasil yang selama ini diperolehnya.

4. Oleh karena itu setidaknya ada 5 hal yang harus diperhatikan dalam kerjasama tersebut, yakni : efisiensi dan optimalisasi manfaat, keterpaduan antarwilayah, keserasian dan keseimbangan, upaya saling membantu dan saling ketergantungan, serta kerjasama yang saling menguntungkan; 
5. Untuk mewujudkan kerjasama yang nyata, maka ada beberapa langkah yang harus ditempuh bersama, misalnya masing-masing wilayah harus mampu menginventarisir dan mengidentifikasi masalah, untuk kemudian didiskusikan dalam "satu meja" dan "satu bahasa" yang koordinatif, kooperatif dan komprehensif guna mencari pemecahannya. Dari hasil ini baru merumuskan langkah nyata bersama untuk memecahkan masalahnya. Dari titik ini satu clearing house bagi semua informasi dan hasil studi atau penelitian pembangunan antarwilayah tersebut perlu dilaksanakan. Tanpa satu bahasa" dan "satu meja" tersebut masingmasing akan berjalan sendiri tanpa koordinasi yang jelas. Oleh karenanya diperlukan komitmen yang kuat bagi masing-masing kepala daerah, bupati, atau walikota. Hal ini merupakan tantangan tersendiri setelah era desentraisasi nampak ada "egoisme" wilayah dan sektoral, ketika para kepala daerah merasa menjadi "raja kecil";

6. Hal lain yang harus disadari, koordinasi pembangunan itu bukan berarti memperbesar wilayah metropolitan sebagai pusatnya, dan juga perlu disadari kerjasama ini tidak otomatis akan mampu mengatasi arus urbanisasi, karena urbanisasi juga terkait dengan kebijakan di tingkat nasional bahkan internasional terkait dominasi kapitalisme dunia;

7. Dalam koordinasi ini juga perlu dibedakan antara istilah administra- tif perencanaan dan istilah administratif pembangunan. Artinya untuk hal-hal yang bersifat detil, tiap-tiap wilayah memiliki otoritasnya sendiri, karena mereka memiliki kekhasan sendiri dan paling paham terhadap masalahnya sendiri. Dengan kata lain, kerjasama sebaiknya hanya di tingkat perencanaan dan implementasi program yang memiliki implikasi kewilayahan bersama.

\section{KESIMPULAN}

Sebagaimana telah dikatakan pada awal tulisan ini, kesenjangan wilayah merupakan hal yang wajar dalam sebuah pembangunan. Masalah pokok yang harus dipecahkan adalah adanya konsepsi kuat untuk jangka waktu yang panjang yang dilandasi keadilan sosial, serta adanya sistem ekonomi politik negara yang tidak memihak terlalu kuat pada wilayah tertentu. Jalan yang harus ditempuh diantaranya bagaimana memberi kemandirian sekaligus dukungan kepada sebuah wilayah sehinga mereka mmiliki daya saing.

Daerah-daerah yang kurang berkembang didorong dengan mobilisasi seluruh kelembagaan, baik dari kalangan perguruan tinggi, LSM, dunia penelitian, pengusaha kecil menengah dan pengusaha besar, lembaga keuangan daerah, lembaga keuangan nasional, serta kemampuan aparatur daerah yang terampil dan memiliki visi misi ke depan yang jelas. Kesemunya mestinya dijalankan dalam sebuah jaringan (networking) yang erat.

Alternatif lain untuk mengatasi kesenjangan sudah banyak dilontarkan oleh beberapa pakar, misalnya melalui teori 
The Centre-Down Development Paradigm. Dalam teori ketidakseimbangan pertumbuhan wilayah, dinyatakan bahwa kekuatan pasar sendiri tidak dapat menghilangkan perbedaan-perbedaan antarwilayah dalam satu negara, bahkan sebaliknya kekuatan-kekuatan ini cenderung akan menciptakan dan boleh jadi malahan memperburuk keadaan.

Kemiskinan di negara-negara sedang berkembang merupakan hasil kerja dari produktivitas tenaga kerja yang rendah yang merupakan bagian dari ketidakcukupan penawaran dan modal-modal fisik. Demikian pula tabungan juga rendah karena pendapatan rendah. Karenanya keseimbangan pertumbuhan dapat diciptakan jika investasi dapat didiversifikasikan ke rentang yang lebih luas di sektor industri. Masing-masing industri akan didorong oleh faktor upah, permintaan barang, dan kecukupan industri yang lain untuk menjaga keberlangsungan kehidupannya. Proyekproyek investasi mungkin secara individual tidak menguntungkan bisa berbalik menjadi menguntungkan.
Strategi pembangunan harus dipusatkan kepada sedikit sektor lalu disebarkan "backward linkage" dan "forward linkage". Jika leading sector dikaitkan dan disebarkan ke berikutnya, dari perusahaan satu ke perusahaan yang lain. Namun yang jelas, kurangnya keterkaitan ke belakang atau backward linkage banyak disebabkan oleh lemahnya permodalan petani di negaranegara sedang berkembang. Pada umumnya para petani sangat tergantung produkproduk pertanian dari luar seperti obatobatan dan pupuk. Akibatnya mereka sering menjadi obyek permainan pasar. Jika panen berlimpah harga turun drastis, jika musim tanam tiba pupuk dan obat-obatan menghilang. Demikian pula teknologi pertanian lainnya seperti inseminator buatan, reparasi alat-alat pertanian atau pelayanan jasa keuangan. Banyak petani yang terjerat renternir dan sistem ijon. Disamping itu, banyak industri modern yang tidak terkait dengan produk pertanian — forward linkage-. Industri padat modal menguasai jaringan dari hulu sampai hilir. Misalnya pabrik supermie, mereka memiliki jaringan tersendiri dan tidak mengambil terigu, cabe, dan rempah-rempah dari petani.

\section{DAFTAR PUSTAKA}

Aziz, Iwan Jaya. 1985. "Pembangunan Daerah dan Aspek Alokasi Investasi

Antardaerah”. Prisma No.6. pp. 3-21

Douglass, Mike.1998. "Urban and Regional Policy After the Era of Native Globalism". Paper presented at the Global Forum on Regional Policy United Nations Center for Regional Development. Nagoya, December 1-4

Dov.Nir, et.All. Region as a Socio-Environmental System : an Introduction to a Systemic Regional Geography. pp. 59-87

Fisher, H.Benjamin.1975. "Perencanaan Regional dalam Konteks Pembangunan Nasional Indonesia". Prisma. No.3 Juni. Pp. 3-10 
Hill, Hal. 1990. "Indonesia`s Industrial Transformation Part I" Bulletin of Indonesian Economic Studies. Vol. 26 No.1. pp. $79-120$ , 1998. "The Challenge of Regional Development in Indonesia" Australian Journal of International Affair 52, No.1

Kiswanto, Eddy. 2005. Analisis Spasial Ekonomi Makro Jawa Tengah (Analisis PDRB Tahun 1993-2003. Forum Geografi. Vol. 19(2) Desember 2005: 154.

Majalah Asiaweek, 25 April 1997

Minshull, Roger.1971 Regional Geography : Theory and Practice, pp. 13-67

Myrdal, Gunnar.1975. Economic Theory and Underdevelopment Region. Duckworth, 26

Nurzaman, Siti Sutriah.1997. “Tinjauan Kesenjangan Wilayah di Indonesia”. Jurnal Perencanaan Wilayah dan Kota. ITB. Vol. 8. No.4. pp.11-21

Perloff, Harvey and Lowdon Wingo Jr.1961. "Natural Resources Endowment and Regional Economic Growth". In Natural Resources and Economis Growth Ed, Joseph J. Spengler. Washington DC: Resources for the Future pp.191-212

Rondinelli, Dennis A. 1985. Applied Methods of Regional Analysis : he Spatial Dimension of Development Policy. pp.1-22

Soedjito, Bambang Bintoro. 1997. "Strategi Pengembangan Kawasan Timur Indonesia" dalam Bunga Rampai Perencanaan Pembangunan Di Indonesia. Jakarta : PT Gramedia Widiasarana Indonesia. Pp. 428-441

Stohr, Water B and D.R.Fraser Taylor.1981. Development from Above or Below? The Dialectics of Regional Planning in Developing Countries. pp. 15-36, pp. 39-69, pp.123-150 